\title{
Analysis of the approach of paleontology in geography textbooks in Ituiutaba, Minas Gerais, Brazil
}

\author{
Emerson J. F. ALVES ${ }^{1 *}$, Gerusa G. MOURA ${ }^{2}$ and Carlos R. dos A. CANDEIRO² \\ ${ }^{1}$ University State of Campinas, Institute of Geosciences. R. John Pandiá Calógeras, 51, \\ University City Campinas, SP - Brazil. \\ ${ }^{2}$ University Federal of Uberlândia, Faculty of Integrated Pontal. Twenty Street, 1600, Tupa, \\ 38304402- Ituiutaba, MG - Brazil.
}

Accepted 17 May, 2013

\begin{abstract}
The textbook is currently one of the driving instruments of teaching and learning. In the analysis of the contents of paleontology in geography textbooks, these books are important because they reveal problems embedded in these works and allow a more informed choice of books for the approach. In this work we performed an analysis of the approach of the contents of paleontology in textbooks of geography, from the perspective of knowing the reality of the current placement of this theme in the books and provided information on the textbooks about the paleontological theme. Five textbooks for geography fundamental schools were chosen, where the basic themes of Paleontology were analyzed. Works examined, four have good approach, including detailed descriptions of the main themes of paleontology. Thus, conceptual definitions were found and described superficially; moreover, new concepts and approaches of scientific knowledge have rarely been incorporated in these teaching materials. We also emphasize the need to consult the recent books of paleontology for the upgrade of the works analyzed, and a better integration of paleontological concepts with other geological interrelated themes. Additionally, improvements in explanations of complex topics are suggested.
\end{abstract}

Key words: Education based on the textbooks, learning dynamics in paleontology, teaching and students' learning

\section{INTRODUCTION}

Textbook is widely used by teachers in the classroom; it has recently acquired a key role in schools of Brazil, directing the process of teaching and learning in basic education. Textbook, compared to the current working conditions of teachers of geography, becomes increasingly an instrument, if not indispensable, at least as a necessary complement to didactic and pedagogical activities.

Throughout the history of Brazilian education, textbook has been very present element and involving several state policies. The quality of textbook presents a constant concern among various authors: Cavalcanti (1998), Castellar and Vilhena (2010). Castrogiovanni (2003),
Vesentini, (2004), Ridley (2006), Tonini and Kaercher (2006), Paganelli (2007) Freeman and Herron (2009) and Callai et al. (2000).

The book is the oldest form of documentation; it records knowledge, ideas and beliefs of the people and its history is closely linked to humanity.

The role of the book as an educational tool is widely recognized by historians of education. Textbook aims first and foremost to contribute to the construction of citizenship, leading to schools and geographic information concepts with methodological correctness and appropriateness.

In times of multimedia computers, distance learning 
and other technology innovations in education, textbook still remains one of the most important media in everyday school life and is undoubtedly the most used and requested. Additionally, the use of the textbook has been justified by the simplifications of the contents and the reduced time for lesson preparation. However, the textbook, the student and professor of geography are all important issues in teaching and learning in schools. For this reason, it is necessary for the teacher to use content from numerous disciplines needed in the teaching of geosciences.

Geoscience is a study of the various processes occurring in the Earth's surface. Geosciences are the sciences that deal with the conditions of development, production and use of concepts, theories and models and scientific institutions as well as research methods and techniques used in teaching and research. This science has established itself as an in-depth research on topics and content designed for natural processes (Alves et al., 2012).

Among the contents in geosciences, paleontology is one. Geoscience (Earth Sciences) is an umbrella term for the sciences related to the planet Earth (Huertas, 2007; Tricart, 1995).

According to Paschoale (1989), numerous sub-areas of geosciences are known within the academic community and society in general and can be distinguished, for example, as: (1) Geology/Physical Geography - studying the constitution and developmental history of rocky parts of the crust (lithosphere) and the surface of the earth, with correlated disciplines like Geology, Mineralogy, Geochemistry, Stratigraphy, Sedimentology, Physical Geology, Geomorphology, GIS, Cartography and Paleontology. Among the subjects covered in Elementary Education, Paleontology is treated primarily within the theme of evolution Geography. Recognition, direct and indirect evidences, including fossil record are the object of study of paleontology.

Geosciences are developed from descriptions of the natural environment, characterized as an inductive science, which is developed from observations and records of local and global phenomena that come from models and formulate hypotheses.

However, the main problems related to the approaches of Paleontology in elementary school are related to the use of textbooks inadequately, the contents which explain paleontology so shallow and inefficiently. The approaches of Paleontology help / contribute as a foundation for understanding the broader issues, surveyed by geography. According to Ridley (2006), Freeman and Herron (2009), this study may lead to understanding of the emergence of life, and provide bases for the study of geographical changes that occur on Earth.

The topics in paleontology textbooks of elementary school are hindered by other areas of the natural sciences, including the dislike between scientific language and everyday language. Moreover, lack of content analysis in textbooks provides the perpetuation of conceptual errors among students, which can be aggravated further with respect to paleontology.

The study involves knowledge from Paleontology Biology, Geography, Physics and Chemistry. These sciences combined enable an integrated understanding of the events and phenomena that enabled the environmental changes and biota during the geological history of our planet.

Paleontology is recommended by the NCP as the theme of science for primary Brazil. In many textbooks in the country approaches to the most complete subject are still scarce in the day-to-day school due to deficiency of more teachers, disinterest or learning difficulties of students. Initiatives described here are working together in the kindergarten, involving the school, teachers and students.

What is proposed is to use literacy and Paleontology in the construction of knowledge, through contact of students with this issue at the beginning of their initial educational activities. The textbook is currently one of the drivers instruments of teaching and learning. Analysis of the contents of paleontology in textbooks is important because it reveals problems embedded in these works and allows a more informed choice of books to address specific content.

It is the most feature presents in the classroom, the main voice in teaching. Admitting as scientific information and safe, the textbook becomes for many teachers, the principal source of update and query.

According to Sposito (2006), the textbook should be understood as an intermediate element in the process of teaching and learning as a commercial product, which contains knowledge for training students, as a product that must have a quality under standpoint of design and durability, and as an object to be bought by the federal government for distribution to schools throughout Brazil. With this conceptual characterization that the book brings with it the determination of public policy is important to the Brazilian basic education, as this incorporates both directly and indirectly the tension between the various issues involved.

We start from the problems that currently exist in the city of Ituiutaba 34 public schools; however, the geography textbooks used by these schools still have no survey on the quality, content quality and settings that deal with paleontology. Thus, this research is justified by research on textbooks, where the quality of content is later found therein. However, from this research, we seek to identify and propose improvements in the quality of textbook of Geography.

In this study we aimed to conduct an analysis on the approach of the content and settings of paleontology in Geography textbooks used in public schools over the city of Ituiutaba (MG), with the goal of portraying the reality of the current placement of the theme in these books and provide useful information to textbooks on geography, 
Table 1. Geography textbooks selected to perform the analysis of the contents of Paleontology $(L=B o o k$ single volume, $C=$ Collection).

\begin{tabular}{|c|c|c|c|c|}
\hline $\mathbf{N}^{\circ}$ & Books and collectibles & Author (s) & Publisher & Year \\
\hline $\mathrm{C} 1$ & Geografia Crítica: O Espaço Natural e a Ação Humana & Vesentini, J. W; Vlach, V & Àtica & 2005 \\
\hline $\mathrm{C} 2$ & Geografia: Espaço e Vivência & $\begin{array}{l}\text { Levon. B; Wanessa. G; Rogério. } \\
\text { M; Andressa. A }\end{array}$ & Atual & 2009 \\
\hline C3 & Geografia: Noções Básicas de Geografia & Melhem Adas & Moderna & 2002 \\
\hline $\mathrm{C} 4$ & Geografia: Projeto Araribá & Moderna & Moderna & 2010 \\
\hline L5 & Conexões: Estudos de Geografia Geral e do Brasil & Lygia T; Regina. A; Raul B. G & Moderna & 2010 \\
\hline
\end{tabular}

with paleontological theme. Nevertheless, it is important to emphasize that the understanding of paleontology makes students to understand the various processes that occur in the formation of the Earth, which makes this research unique to educational knowledge.

The importance of researching the teaching of paleontology lies in being able to give students geological concepts, thus informing them of the formation processes of planet Earth, which is essential for facilitating their learning and helps them understand the terrestrial periods and processes for modifying the structure of the earth. This way, students will begin to have practical reasoning about land formations.

\section{MATERIALS AND METHODS}

This research consisted of a literature review or documentary, where the data were processed data. For the analysis were chosen five of Geography textbooks among those listed by the National Textbook Program - PNLD because we believe that these books are the most comprehensive, and most are used in the classroom. The collections comprise sets of books published in volume/ collections, intended for Elementary Education.

In analyzing the contents some topics selected were related to Paleontology, in specific topics to essences: concepts and importance of knowledge of the Dinosaurs, and the processes that occur over time. For these subjects, we observed the following: presence or absence in the books, conceptualization of the theme. Therefore, we evaluated five textbooks of geography (Table 1).

In the data analysis, quantification of the percentage of the contents of Paleontology in the books analyzed followed the method used by Beneti et al. (2009). In this method the percentage of the specific content approach is measured by the relationship made between the number of pages and content analyzed for the total number of pages of the book under review. At the end of the analysis, we recorded values attributed to the presence and quality of the topics analyzed in this study. The values are: Good quality explanation of theme proposed point $=5$; Presence theme $=4$ points; Proposal conceptual Good $=3$, 5; Focus contextual Paleontology $=3$; Relevance in the context of the topic $=2$; Appearance as coerrente processes studied by Paleontology $=2.5$; Approach superficial theme $=1$ point $($ Table 2 ).

\section{ANALYSIS OF THE RESULTS}

Paleontology in Geography textbooks is related to use of information on the evolution and culmination of living beings. This science is often associated with discussions on the origin of plants, animals, and that microorganisms exist in the processes of geologic time permeated by the Earth.

The study covers the notions derived Paleontology Geology, Biology, Geography, Physics, Chemistry and Mathematics. This science is recommended as a subject in basic education, being claimed in textbooks.

The collections and books researched content relating to paleontology exhibit themselves in various diluted textual parts. In the first collection, these contents are inserted into chapters dedicated to Evolution, Origin of Life, Introduction to Animals such as Dinosaurs. In this work, the basic concepts of Paleontology are mentioned, including the definitions of Paleontology, fossil extinctions and geological time.

In the second collection, the content of Paleontology is light/shallow, with few citations in two chapters, which comprise the object of study of Biology and Biological Evolution. In this book the basics of paleontology are not mentioned, resulting not only in restricting understanding of paleontological topics, but also discussions involving fossils contained in broader issues that interface with paleontology.

In collection 3, the basic themes studied are divided into several chapters, incorporating information about different zoological and botanical groups, origin of life, evidence of biological evolution and the emergence of major groups of organisms. The approach of the basic issues is so broad, enabling the breakdown of major paleontological information.

In collection 4, Paleontology regarding the contents is less expressive, being registered in the chapters for the Origin of Life and Evolution of Evidence. This book presents, in the chapter "Evidence of Evolution", a text that provides several complementary explanations about the fossil record. This text is more informative than the text contained within the chapter itself, which is quite brief.

The information contained in the text includes text that explains the fossils as evidence of biological evolution, fossils, their training and their applications within the understanding of the evolutionary process. In book 5, the 
Table 2. Analysis of the presence and quality of the applications of Paleontology analyzed based on established values.

\begin{tabular}{|c|c|c|c|c|c|}
\hline Evaluation of paleontology & Collection 1 & Collection 2 & Collection 3 & Collection 4 & Book 5 \\
\hline $\begin{array}{l}\text { Good quality of the explanation of the proposed } \\
\text { theme }\end{array}$ & 5 & 0 & 5 & 0 & 5 \\
\hline Presence theme & 4 & 4 & 4 & 4 & 4 \\
\hline Good conceptual proposal & 3.5 & 0 & 3.5 & 0 & 3.5 \\
\hline $\begin{array}{l}\text { Paleontology contextual approach to other areas } \\
\text { of knowledge }\end{array}$ & 3 & 3 & 0 & 3 & 3 \\
\hline Revelância in the context of the theme & 0 & 0 & 2 & 2 & 0 \\
\hline $\begin{array}{l}\text { Coerrente aspect regarding the processes studied } \\
\text { by paleontology }\end{array}$ & 0 & 2.5 & 0 & 2.5 & 0 \\
\hline Superficial approach the topic & 1 & 1 & 0 & 1 & 0 \\
\hline Overall & 16.5 & 10.5 & 14.5 & 12.5 & 15.5 \\
\hline
\end{tabular}

contents of Paleontology make up the overall content of the work and fall in broader issues such as Biological Evolution and the Origin of Life, along with brief comments on fossils contained in chapters relating to Zoology and Botany. The texts are provided, addressing the divisions of geologic time, paleogeographic changes on Earth over time. Furthermore, this collection mentions the current problems linked to the possible fact that the oldest fossil is records of Earth.

\section{The concept of paleontology vs textbooks}

Paleontology is the science that records the existence of living organisms on Earth's past. This evidence may present itself in the information of fossils. These are the remains or traces of bodily activity of living beings. The understanding of Paleontology is a fundamental prerequisite for the discussion of more specific topics focused on evolution and origin of life processes.

In the third collection concept of Paleontology is displayed more than once, however, appears lightly. That is because, the content and settings studied by science paleontology impoverishment explains the definitions and concepts of science paleontological making it easy to understand the importance of this natural science.

In the paleontology collection 2, it is not defined/ conceptualized, which compromises the understanding of how a science helps to understand the evolutionary process. Regarding text books of geography, it was found that they are suitable as palaeontology.

From the analysis of textbooks, the concepts were used in the classroom. Dealing with specific ideas are mentioned in Paleontology Collection 2, the collection includes text where the importance of Paleontology in science is not revealed, but it represents ideas about the formation process of the Earth and knowledge about the operation and maintenance of the fossils.

In collection 4 palaeontology superficially is mentioned, precluding understanding of the context in which this science hinders the understanding of science that studies. However, no mention of paleontology through descriptions/information that presents the major physical, biological, geological changes on Earth. Thus, it makes no mention of the geological time disassociating the Paleontology of natural processes, which in turn interferes with the organization in understanding and perception of time involved in the evolution of living beings. The knowledge explained in the form of educational content is proposed superficially, since they are descriptions of the formation of the first living things, cooling the planet earth, the formation of the oceans, the appearance of the first amphibians, emerging and extinction of the dinosaurs, occurrence of the first mammals, the development of agriculture, among others.

Collections 1 and 5 are the only ones that present a more detailed content, giving a better final evaluation. Processes of Paleontology are related to types of studies that form this science. These collections consider the study of paleontology as evidence of evolutionary processes, the key to understanding the origins of life on Earth, allowing the reconstruction of geological processes- biological, chemical and physical.

\section{DISCUSSION AND CONCLUSION}

From this analysis we can consider that: 1 and 3 collections have broader approach of the basic themes of Paleontology, compared with the other collections; however, the approach is correct and most complete collection is 1 , which describes correctly the theme. The contents of Paleontology are encompassed as part of paleontological references. The definition of Paleontology is still displayed in collections, and receives little attention. The conceptual confusions and errors are present in the books, with no distinction of subject studied. In this sense, there are insufficient upgrades that incorporate 
new information from the scientific community.

Based on this analysis, it is recommended to authors of books for Geography for Elementary Education in definition of concepts, to use current and accurate classifications for Paleontology. We also emphasize the need for greater coordination between the concepts- paleontological and geological issues that have interface with Paleontology, Geography, Geology, and Geomorphology.

Importantly, the content is presented in the textbook as collections and is adding to the teaching-learning from scientific knowledge; the contents are presented in a superficial way and provide basic issues related to Palaeontology. In this collection, teaching observed is during the Cretaceous period and differs from other books that were analyzed, in that it is primarily with issues related to the structure and processes contained in the formation of the Earth.

The collections and researched book should be understood as an element of intermediation in the process of formation, as a product that contains the knowledge necessary for the formation of the student. Knowledge of Geosciences should be related to natural changes and its subsequent amendments, revealing issues relating to natural processes studied by paleontology, as well as issues related to the periods of land transformation.

These changes are mainly due to the improvement of education professionals, students and Geography books, since it is important to note the commitment to teaching and learning that enables critical and analytical thinking. To assess the content of the book "Geography: Building Awareness" you need to consider issues related to teaching sixth grade.

Importantly, this book formalizes matters of geological issues and should be considered as a source of knowledge that facilitates comprehension processes and geological structures. Based on research done in textbooks, it is recommended to authors of textbooks and collections of Geography for Elementary Education in conceptual use, to use current and accurate classifications for Paleontology.

It is emphasized also the need for greater coordination between the concepts- paleontological and geological issues. Thus, one should explain clearly and adequately the importance of paleontology to understand the evolution of the processes occurring on Earth.

Finally, for this reason, the use of texts that can complete auxiliary didactic, the texts are recommended, for example, Briggs and Crowther (2003), Benton (2008), Benton and Harper (2009), Ridley (2006) and Freeman and Herron (2009). Current works are suggested for finding more accurate information on this topic; for example work on aula, Todavia room, we suggest expanding and improving comprehensive explanations related to topics in the natural sciences, which are essential for understanding natural processes.

\section{REFERENCES}

Alves EJF, Moura GG, Candeiro CRA (2012). A importância Extensionista o Projeto Ciências da Terra: Praticando e Compreendendo as Geociências na Região do Pontal do Triângulo Mineiro. Revista Caminhos de Geografia 13:231-239.

Beneti JS, Pereira SIR, Gioppo C (2009). Reino Monera: uma análise comparativa de quatro livros didáticos de Ciências da $6^{\underline{a}}$ Série $\left(7^{\circ}\right.$ Ano) do ensino Fundamental. In: SIMPÓSIO NACIONAL DE ENSINO DE CIÊNCIA E TECNOLOGIA, 1, Curitiba, 2009. Trabalhos Completos, Curitiba, UTFPR pp.440-461.

Benton MJ (2008). Paleontologia dos Vertebrados. São Paulo, Atheneu p.464.

Benton MJ, Harper DAT (2009). Introduction to leobiology and the fossil record. Oxford, Blackwell Science p.608.

Briggs DEG, Crowther PR (2003). Paleobiology II. Oxford, Blackwell Science p.600.

Callai H (2000). Estudar o lugar para compreender o mundo. In: Castrogiovanni AC (Org.). Ensino de geografia: práticas e textualizações no cotidiano. Porto Alegre: Mediação.

Castellar S, Vilhena J (2010). Ensino de Geografia. São Paulo: Ed. Cengage Learning. Coleção ideias em ação pp.137-145.

Castrogiovanni AC (2003). Geografia em sala de aula práticas e reflexões. Porto Alegra: Ed. UFRGS. 4. Ed. p.197.

Cavalcanti Lde S (1998). Geografia, Escola e Construção de Conhecimentos. Campinas: Ed. Papirus.

Freeman S, Herron JC (2009). Análise Evolutiva. Porto Alegre, Artmed p.848.

Huertas DM (2007). Do Além dos Aspectos puramente Acadêmico: O Trabalho de Campo Como UMA Verdadeira Experiência de Vida. Espaço e Tempo, São Paulo pp.149-156.

Paschoale C (1989). Geologia Como semiótica da Natureza. São Paulo. Dissertação (Mestrado)-Pontifícia Universidade Católica de São Paulo. São Paulo.

Ridley M (2006). Evolução. Porto Alegre, Editora Artmed p.752.

Sposito MEB (2006). Livros Didáticos e História e Geografia: Avaliação e pesquisa. São Paulo: Ed. Cultura acadêmica.

Tonini IM (2006). Geografia Escolar: Uma história sobre seus discursos pedagógicos. Rio Grande do Sul: Ed. Unijuí. 2.ed.

Tricart J (1995). A Dialética da Geologia (Geologia e Temas inspirados nd obra de Friedrich Engels e SUA applications). Revista Brasileira de Geociências, São Paulo 9(25):107-110.

Vesentini JW (2004). Ensino de Geografia no Século XXI. Campinas: Ed. Papirus p.249. 